\title{
Informed consent in embryonic stem cell research: Are we following basic principles?
}

\author{
Timothy Caulfield, Ubaka Ogbogu, Rosario M. Isasi
}

$\mathrm{T}$ he question of whether stem cell research involving human embryos is morally acceptable has dominated much of the national and international dialogue, including parliamentary debates in Canada., ${ }^{1,2}$ Many of the policies surrounding the ethics of stem cell research were developed in this highly contentious environment. As such, there seems to have been only minimal discussion of how basic legal and ethical research norms, including consent principles, might play out in this context. In this article, we consider 2 unresolved consent issues relevant to embryo donation for stem cell research: who should obtain consent and does the donor have the right to withdraw consent.

\section{Who should obtain consent?}

Under existing Canadian regulations, only embryos donated by people who no longer require them for reproductive purposes can be used for stem cell research. ${ }^{3}$ In practice, this means that embryos are obtained from clinics that provide reproductive technology services. Researchers must satisfy both the local and the national research ethics boards (the national being the Stem Cell Oversight Committee) that all consent requirements have been met. ${ }^{4}$ These requirements include the condition that the treating physician will not be the person who obtains consent from the embryo donor. ${ }^{4}$ In addition, the treating physician cannot be involved in the stem cell research protocol. ${ }^{4}$

This policy reflects the understandable concern about conflicts of interest and the possibility that a physician may put undue influence on patients to donate their embryos. As noted by Lo and colleagues, ${ }^{5}$ people receiving infertility treatment are so dependent on their physician "that they might consent to anything that the doctor requests or even presents."

These rules have recently been applied to one of the few embryonic stem cell derivation projects in Canada. In April 2006 the Stem Cell Oversight Committee provided "conditional approval of the application pending the receipt and review of statements that the respective caring physician will not be the individual obtaining consent."

Despite the concerns and the recent decision by the Stem Cell Oversight Committee, there is no clear consensus within the international community on who should seek consent. Indeed, guidelines and policy statements differ greatly (Table I). However, most policies contain no explicit recommendation that the treating physician be removed from the consent process.

Table 1: National and international guidelines on who should seek patient consent for embryo donation

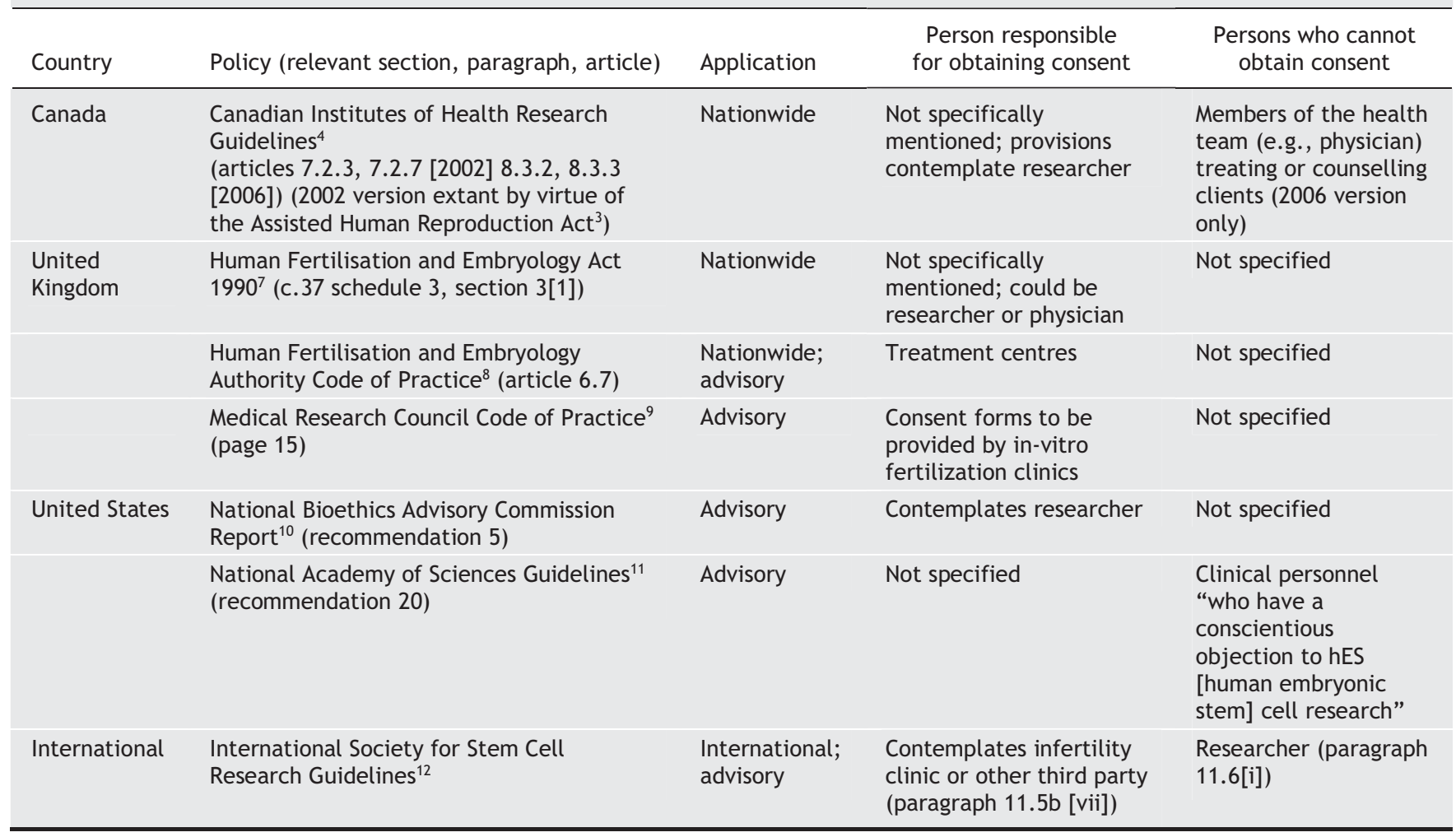


Although hardly definitive, Canadian consent law suggests that the treating physician, if unaffiliated with embryonic stem cell research, should be the person to obtain consent. In general, Canadian law has historically placed the onus for obtaining and administering consent on the treating physician. ${ }^{13}$ The physician has a duty of care to the patient that includes a requirement to provide enough information for the patient to make an informed decision. The embryos are being created in a clinical situation over which the treating physician has ultimate legal responsibility. Physicians have a relationship with the patient and are familiar with their history, needs and concerns. As such, the treating physician is in a good position to provide information that "a reasonable person in the patient's position" would want to know. ${ }^{14}$

Canadian physicians are also in a fiduciary relationship with their patients. This compels the physician to place the best interest of their patient first and to treat them with "utmost good faith and loyalty." ${ }^{15-17}$ It is less clear whether another relevant person, such as a stem cell researcher or an independent third party, would have the same legal obligations. ${ }^{18}$ This case law was developed to address the exact concerns emerging in this context and serves as legal foundation for a consent process focused on the needs of the donor. As noted by Lo and colleagues, ${ }^{5}$ "if the patient's physician is not an investigator in the [stem cell] study, he or she is focused on the patient's well being rather than the potential social and scientific benefits of the research."

Finally, it should not be forgotten that physicians control the consent process in a variety of other situations in which they may be in a conflict or in a position to exert undue influence. For ex- ample, treating physicians are generally responsible for obtaining consent in most clinical research situations, including those in which the risks of dependence are profound (e.g., cancer research) or in which the physician may be receiving remuneration for patient recruitment. ${ }^{19}$ Likewise, the financial remuneration that infertility specialists receive for providing clinical services also creates a conflict. The more services they provide, the more money they make. We are not saying that these situations are not problematic. However, the conflict-of-interest issues generated by these situations are probably more substantial than those that might arise if a treating infertility physician is involved in the consent process. In most situations, the conflict issues are usually dealt with not by creating a new consent regime, but by full disclosure, by the imposition of fiduciary obligations and by moderating the circumstances that create the conflict. ${ }^{20}$

We should apply consent principles consistently or we risk creating a patchwork of approaches that will confuse researchers and research ethics committees and that, in fact, will jeopardize patient rights and the protection of research participants.

\section{The right to withdraw consent}

One of the most fundamental principles of consent and research ethics is that people retain the right to withdraw their consent for medical procedures or research trials at any time. In the clinical context, numerous cases have affirmed this right, ${ }^{13}$ and a strong expression of an almost unqualified right can be found in guidelines throughout the world. Indeed, it stands as a basic tenet of research ethics (Table 2).

Table 2: Research ethics policies about when patient consent can be withdrawn

Policy (relevant section, paragraph, article)

Withdrawal cut-off

\section{General research}

Helsinki Declaration ${ }^{21}$ (paragraph 22)

Council of Europe Convention on Human Rights in Biomedicine $^{22}$ (article 14)

Tri-Council Policy Statement ${ }^{23}$ (article 2.2)

\section{Stem cell research}

Proposed Assisted Human Reproduction (Section 8 Consent) Regulations $^{24}$ (Section 14)

Canadian Institutes of Health Research Guidelines ${ }^{4}$ (article 8.3.3)

Stem Cell Network Policy Statement ${ }^{25}$

Human Fertilisation and Embryology Act $^{7}$ (schedule 3, paragraph 4)

Human Fertilization and Embryology Authority Code of Practice $^{8}$ (articles 5.8, 6.8)

National Academy of Sciences Guidelines ${ }^{11}$ (recommendation 17)

International Society for Stem Cell Research Guidelines ${ }^{12}$ (paragraph 11.2)

\author{
"At any time without reprisal" \\ "Consent may be freely withdrawn ... at any phase of the research" \\ "Consent must be freely given and may be withdrawn at any time"
}

Before the latest of the following occurrences: (a) researcher acknowledges in writing that the embryo has been designated for research, (b) the beginning of the process of thawing the embryo for research or (c) creation of a stem cell line

Creation of an anonymized cell line

Use of embryo in cell line derivation

Use of embryo for the purpose of any research project

Use of embryo for the purpose of any research project

Use of blastocysts in cell line derivation

Use of materials (embryos) for research 
Legal and ethical norms tell us that this right extends to identifiable health information and linkable tissue removed from the body. ${ }^{26}$ Canadian case law has stated that identifiable health information implicates "personal integrity and autonomy." ${ }^{16}$ Article 8.6 of Canada's Tri-Council Policy Statement, which relates to the banking of genetic material, embraces this perspective and declares that, even in the context of tissue collection, the right to withdraw consent endures and could include the destruction of the research material. ${ }^{23}$ The Helsinki Declaration notes that medical research on human subjects "includes research on identifiable human material or identifiable data." 21

Despite this tradition, many policies about research on embryonic stem cells limit the right to withdraw consent to a specific time during the research process, usually to any time before a stem cell line is created (Table 2 ). One can certainly see why, from the perspective of researchers, it is desirable to have a clear cut-off for when consent can be withdrawn. Allowing research participants to withdraw their consent after a cell line has been created could create unique and profound problems for researchers. Indeed, a stem cell line could end up in hundreds of laboratories throughout the world. However, this logistical reality needs to be explicitly balanced and reconciled with the general principle that the goals of research do not supersede individual rights. ${ }^{21,22}$ Likewise, in analogous situations, such as biobanking projects, most policy documents explicitly note the existence of the right to withdraw consent. ${ }^{27,28}$

It may be argued that the traditional conception of the right to withdraw consent is not applicable in this context because the embryo is a new entity with special status. In other words, the embryo is a separate entity from the gamete and embryo donors. This argument creates a "special status paradox" whereby the proponents of the view reject vesting a special status on the embryo for the purpose of performing research on the embryo, but they allow such status for the purpose of avoiding established research ethics principles. Likewise, the fact that researchers have added their labour to transform the tissue into a new form that remains linkable and relevant to its donors cannot, on its own, extinguish an autonomy-derived right - as highlighted by the withdrawal policies associated with research on biobank material and research involving other forms of personal information.

Consent to research is not a binding contract. Research participants retain the right to change their mind without repercussions, regardless of what they agreed to at the start of the proposal (again, a truism found in virtually every research ethics policy). In the context of stem cell research, there are reasons why this right may be viewed as particularly important. The research remains controversial and involves highly contested and strongly held moral positions. In such an environment, ensuring that donors' wishes are respected seems especially important. In addition, consent will probably be obtained in a clinical setting where donors are involved in a sensitive medical procedure. With the passage of time and distance from the clinical encounter, donor opinions may change. Finally, stem cell lines are capable of revealing health information about the donor. In other words, the stem cell line could be viewed as an extension of the donor's health record, something that the patient clearly retains the right to control. ${ }^{16}$

That said, the degree to which consent law extends to tissue and genetic information used in research has not been addressed by a Canadian court and remains a controversial topic in other jurisdictions. ${ }^{29}$ Also, allowing the right to withdraw consent to extend to stem cell lines could have a considerable adverse impact on the research environment, a reality that must be considered. At a minimum, however, the strength of the relevant jurisprudence and the long tradition of upholding the right to withdraw consent in other clinical research contexts suggest that a deviation from the wellestablished norm requires convincing and explicit rationales that can be logically reconciled with existing principles of legal and research ethics.

Of course, if a stem cell line is made truly anonymous, withdrawal of consent will not be possible. In such circumstances, donors should be made aware of this during the consent process. However, in the current environment, it seems unlikely that a stem cell line could be made truly anonymous. There are currently so few stem cell lines in Canada that anonymity could never be fully achieved. In addition, this may not be a desirable course of action. Having continuing access to the health status of the donor may be necessary if, for instance, a cell line is to be used for clinical trials. Traceability of stem cell lines is an internationally accepted ethical and scientific standard for stem cell research, and this requirement has been incorporated into a number of national policies. ${ }^{11,30}$ It has recently been suggested that, in the context of stem cell research, "donor contact information should be kept current to facilitate rescreening." ${ }^{31}$ It seems self-evident that, if linkage and recontact is required, the right to withdraw consent, at some level, should endure.

\section{Conclusion}

Although consent policies are always evolving, the rationales that underlie the existing consent norms should not be ignored. We need to be sure that the hype and social controversies that have surrounded this area of research do not lead us to overemphasize either the benefits or the risks. ${ }^{32-34} \mathrm{We}$ should avoid overly protectionist assumptions that would have us alter the usual approach to obtaining consent, including allowing clinicians to obtain the necessary consent. Likewise, we should be careful not to let the understandable excitement about the value of the research erode long-established consent rights, including the right to withdraw consent. If unique consent rules are to be applied to this area of research, the rationales for the approach need to be clearly articulated and reconciled with existing principles of consent and research ethics.

\section{This article has been peer reviewed.}

Timothy Caulfield holds the Canada Research Chair in Health Law and Policy. He is a professor in the Faculty of Law and the School of Public Health and is Director of the Health Law Institute, University of Alberta. Ubaka Ogbogu is with the Health Law Institute, University of Alberta, Edmonton, Alta. Rosario M. Isasi is with the Centre de recherche en droit public, Faculty of Law, University of Montréal, Montréal, Que. 
Competing interests: None declared.

Contributors: All of the authors contributed to conceiving and writing this commentary and approved the final version for publication.

Acknowledgements: We thank Erin Nelson, Jeff Nisker, Kanchana Fernando, Vincent Kurata, Yoko Azumaya, Nina Hawkins, and the Health Law Institute and Centre de recherche en droit public research teams for their assistance in the preparation of this article.

We thank the Stem Cell Network and the Alberta Heritage Foundation for Medical Research for funding support.

\section{REFERENCES}

I. Caulfield T, Bubela T. Why a criminal ban? Analyzing the arguments against somatic cell nuclear transfer in the Canadian parliamentary debate. Am J Bioeth 2007;7:5I-6I.

2. Isasi RM, Knoppers BM. Mind the gap: policy approaches to embryonic stem cell and cloning research in 50 countries. EurJ Health Law 2006;13:9-26.

3. Assisted Human Reproduction Act. SC 2004, c2. Available: http://laws .justice.gc.ca/en/ShowFullDoc/cs/a-I3.4///en (accessed 2007 Apr 20).

4. Canadian Institutes of Health Research (CIHR). Updated guidelines for human pluripotent stem cell research, June 28, 2006. Ottawa: CIHR; 2006. Available: www.irsc.ca/e/3I488.html (accessed 2007 Apr 20).

5. Lo B, Chou V, Cedars MI, et al. Informed consent in human oocyte, embryo, and embryonic stem cell research. Fertil Steril 2004 Sep; 82;559-63

6. Canadian Institutes of Health Research. Minutes of the 7 th meeting of the Stem Cell Oversight Committee (SCOC). Ottawa: CIHR; 2006 April 6-7. Available: www.cihr-irsc.gc.ca/e/31508.html (accessed 2007 Apr 20).

7. Human Fertilisation and Embryology Act I990, c37. Available: www.opsi.gov.uk /acts/actsi99o/Ukpga_I9900037_en_I.htm (accessed 2007 May 2).

8. Human Fertilisation and Embryology Authority. Code of practice. 6th ed. London (UK): The Authority; 2003. Available: www.hfea.gov.uk/docs/Code_of_Practice Sixth_Edition_-_final.pdf (accessed 2007 May 2).

9. Medical Research Council (MRC). Code of practice for the use of human stem cell lines, September 15, 2006. London (UK): MRC; 2006. Available: www.mrc.ac.uk /Utilities/Documentrecord/index.htm?d=MRCo03132 (accessed 2007 May 2).

Io. National Bioethics Advisory Commission. Ethical issues in human stem cell research, Vol.I. Rockville (MD): The Commission; I999. Available: www.georgetown .edu/research/nrcbl/nbac/stemcell.pdf (accessed 2007 May 2).

II. Committee on Guidelines for Human Embryonic Stem Cell Research. Guidelines for human embryonic stem cell research. Washington (US): National Academies Press; 2005.

12. International Society for Stem Cell Research. Guidelines for the conduct of human embryonic stem cell research. Northbrook (IL): The Society; 2006. Available: www.isscr.org/guidelines/ISSCRhESCguidelines2006.pdf (accessed 2007 Apr 20).

I3. Ciarlariello v. Schacter (I993), SCR, II9. Available: http://scc.lexum.umontreal.ca len/I993/I993rcs2-II9/I993rcs2-IIg.pdf (accessed 2007 Apr 20).

14. Reiblv. Hughes (I980), SCR, 880.

I5. Norbergv. Wynrib (I992), SCR, 318

I6. McInerneyv. McDonald (I992), SCR, I38.

17. Nisker J. The CMA code of ethics and the donation of fresh embryos for stem cell research. CMAJ 2005;173:62I-2.

I8. Litman MM. Fiduciary law and for-profit and not-for-profit health care. In: Caulfield TA, von Tigerstrom B, editors. Health care reform and the law in Canada meeting the challenge. Edmonton: University of Alberta Press; 2002. p. 85-1 30.

I9. Caulfield T, Griener G. Conflicts of interest in clinical research: addressing the is sue of physician remuneration. J Law Med Ethics 2002;30:305-8.

20. Lemmens T, Singer PA. Bioethics for clinicians: 17 . Conflict of interest in research, education and patient care. $C M A J$ I998;159:960-5.

2I. World Medical Association. Declaration of Helsinki: Ethical principles for medical research involving human subjects. JAMA 2000;284:3043-5.

22. Council of Europe. Additional protocol to the Convention on Human Rights in Biomedicine, concerning biomedical research: Strasbourg 25.I.2005. Strasbourg (Germany): The Council; 2005. Available: http://conventions.coe.int/treaty/en /Treaties/Html/I95.htm (accessed 2007 Apr 20).

23. Canadian Institutes of Health Research, Natural Sciences and Engineering Research Council of Canada, Social Sciences and Humanities Research Council of Canada. Tri-council policy statement: ethical conduct for research involving humans I9g8 (with 2000, 2002, 2005 amendments). Ottawa: Public Works and Government Services Canada; 2005.

24. Canada, Governor-in-Council. Draft Assisted Human Reproduction (Section 8 Consent) Regulations, September I9, 2006. Copy on file with authors.

25. Policy Development Committee, Canadian Stem Cell Network. Use of human em bryos for stem cell research. Ottawa: The Network; 2006. Available: www.stemcellnetwork.ca/aboutus/policy.php (accessed 2007 May 2).
26. Perley SN. From control over one's body to control over one's body parts: extending the doctrine of informed consent. NY Univ Law Rev 1992;67:335-65.

27. UK Biobank. UK Biobank ethics and governance framework, version 2.0, July 2006. Available:www.ukbiobank.ac.uk/docs/EGF_Version2_July\%2006\%2omost \%2ouptodate.pdf (accessed 2007 May 2)

28. German National Ethics Council. Biobanks for research: opinion. Berlin: Nationaler Ethikrat; 2004. Available: www.ethikrat.org/_english/publications/Opinion Biobanks-for-research.pdf (accessed 2007 Apr 20).

29. The Washington University v. William J. Catalona et al, No 4: $0_{3} \mathrm{CV}_{10}{ }_{5} \mathrm{SNL}$ (US District Court Opinions). Available: www.circare.org/lex/o3cvoro65_opinion.pdf (accessed 2007 Apr 20).

30. Code of federal regulations. 2I: Eligibility determination for donors of human cells, tissues, and cellular and tissue-based products; final rule and notice. s. I27I.55. Washington (DC): US Food and Drug Administration, Department of Health and Human Services.

3I. Halme DG, Kessler DA. FDA regulation of stem-cell-based therapies. N EngIJ Med 2006;355:1730-5, I732.

32. Morelle R. Stem cells: Hope or hype? BBC News, UK version; 2006 Nov 9. Available: http://news.bbc.co.uk/2/hi/health/6127772.stm (accessed 2007 Apr 20).

33. Amos J. Winston warns of stem cell "hype". BBC News, UK version; 2005 Sept 5 Available: http://news.bbc.co.uk/2/hi/science/nature/4213566.stm (accessed 2007 Apr 20)

34. Caulfield T. Popular media, biotechnology, and the cycle of hype. Houst J Health Law Policy 2005;5:213-33.

Correspondence to: Timothy Caulfield, Health Law Institute, Law Centre, University of Alberta, gI University Campus NW, Edmonton AB T6G 2H5; fax 780 492-9575;

tcaulfld@law.ualberta.ca

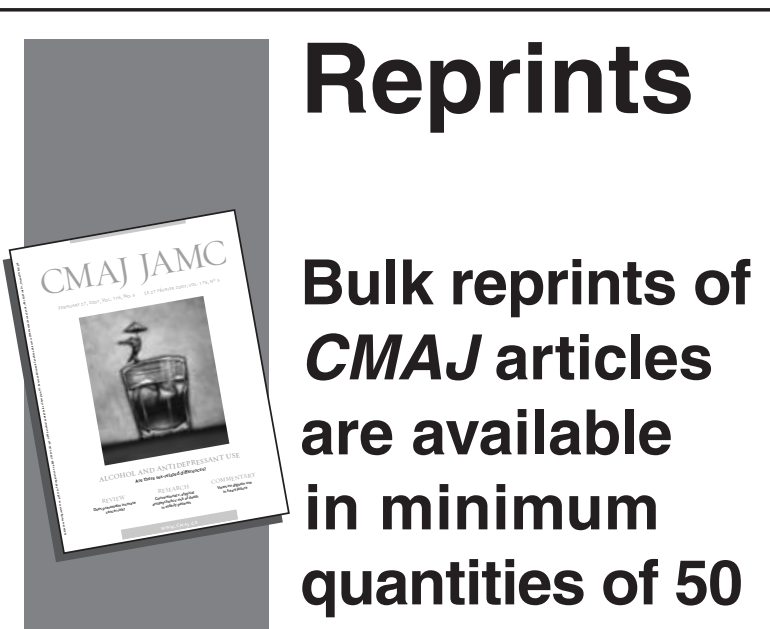

For information or orders:

Reprint Coordinator

tel $800663-7336$ x2110

fax 613 565-7704

janis.murrey@cma.ca

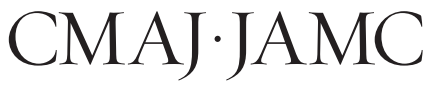

